\title{
Effect of Phytobiotics Supplementation on Carcass Characteristics of Nandanam Broiler 3 Chicken
}

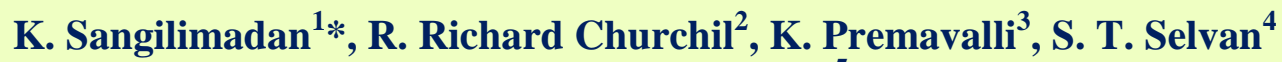 \\ and A. V. Omprakash ${ }^{5}$ \\ ${ }^{1}$ Department of Poultry Science, Madras Veterinary College, Chennai-7, India \\ ${ }^{2}$ Poultry Research Station, Madhavaram Milk Colony, Chennai- 51, India \\ ${ }^{3}$ Research Institute of Animal Sciences, Kattupakkam, Chennai-603 203, India \\ ${ }^{4}$ Department of Poultry Science, Madras Veterinary College, Chennai-7, India \\ ${ }^{5}$ Centre for Animal Production Studies (DCAPS, \\ Tamil Nadu Veterinary and Animal Sciences University, MMC, Chennai-51, India \\ *Corresponding author
}

\section{A B S T R A C T}

Keywords

Phytobiotics, Ginger, Garlic,

Turmeric, carcass yield, cut-up-parts

Article Info

Accepted:

10 April 2020

Available Online:

10 May 2020
A study was conducted to evaluate the effect of phytobiotics on carcass characteristics of Nandanam broiler-3 chicken. A total of 120 day-old Nandanam broiler-3 chicks were randomly allotted into four treatments with three replicates each 10 chicks. The dietary treatments were formulated as control fed with basal diet (T1) and basal diet supplemented with $0.50 \%$ ginger powder (T2) or garlic paste (T3) or turmeric powder (T4). At the end of 8 weeks of age, six birds ( 3 males and 3 females) were randomly selected and subjected to slaughter studies to determine the carcass characteristics. The results indicated that digestive stimulant effect of turmeric (T4) had resulted in increased per cent eviscerated $(63.71 \%)$ and ready-to cook $(69.71 \%)$ weights which is followed by other treatment groups (T2 and T3) compared to control (T1). The per cent cut-parts of breast, back, thigh and wings were significantly $(\mathrm{P}<0.05)$ higher in $\mathrm{T} 4$ compared to other treatment groups. Significant $(\mathrm{P}>0.05)$ differences were observed in per cent head, gizzard and intestine length $(\mathrm{cm})$ among the treatments. There was no significant difference observed in per cent blood, feather, shank, liver, heart and giblets. There was no significant difference observed on drumstick and neck parts also.

\section{Introduction}

Poultry industry can harvest first class protein for human nutrition, as a source of revenue and play an important role in economic growth of any country (Tarhyel et al., 2012).
In the past, antibiotics were the regularly used as feed additives to improve the meat and egg production of chicken. However, the use of antibiotics is facing serious criticism (Iji et al., 2001) and restricted due to drug residue in carcass and also due to modification of 
natural gut micro flora (Botsoglou et al., 2002). Recently, many countries banned the use of antibiotics because of their harmful side effects and due to increased awareness; the alternatives to antibiotics such as, herbs and medicinal plants are being widely used now (Manseh et al., 2012). Nutritionists are shifting their attention from utilization of chemical to phytogenic growth promoters in recent years (Iji et al., 2001). Ginger, garlic and turmeric can be used as good alternatives for common artificial growth promoters like antibiotics. Hence, this study was conducted with these three different phytobiotics as feed additives to study the effect on carcass characteristics in Nandanam broiler chicken3.

\section{Materials and Methods}

The study was carried out at Poultry Research Station, Madavaram Milk Colony, Tamil Nadu Veterinary and Animal Sciences University, Chennai, located between $13^{\circ}-9^{\prime}$ and $13^{\circ}-15^{\prime} \mathrm{N}$ and longitudes $80^{\circ}-14^{\prime}$ and $80^{\circ}$ - 24' E with an altitude of 22 meters above mean sea level. Chennai has a hot and humid climate, classified as 'Tropical Maritime Monsoon' type. The average annual rainfall is $130 \mathrm{~mm}$ and depends mostly on the North East monsoon. Average temperature was $28.4^{\circ} \mathrm{C}$ during the study period (December to February). The relative humidity was high throughout the year in range of 65-85 per cent.

\section{Experimental design}

A total of one hundred and twenty Nandanam broiler-3 chicks with average hatch weight of $36.67 \mathrm{~g}$ were distributed randomly into four groups having three replicates of each ten birds in a Completely Randomized Design. The standard recommended commercial broiler diet was prepared as per BIS (2007) broiler standards with similar nutrient composition for all the treatments. The design of experiment is presented in Table 1. The control diet was formulated without supplementation of any antibiotics, growth promoters yeast or prebiotics (T1). The experimental diets were prepared by supplementing the control diet with 0.50 per cent ginger powder (T2) or 0.50 per cent garlic paste (T3) or 0.50 per cent turmeric powder (T4). The required amount of various phytobiotics were prepared and weighed and initially mixed with small quantity of feed and then mixed with bulk quantity. All the diets were isocaloric and isontrogenous. The feed and water were provided ad libitum during the experimental periods. Standard management practices were adopted in all the experimental groups. At the end of eight weeks experimental period, six birds for each treatment ( 3 males +3 females) were picked up randomly and slaughtered by standard method.

\section{Dressed yield}

The dressed yield of the carcass was determined as per ISI Standard. The dressed yield of the carcass was recorded after removing blood, feather, shank, oil gland, head and viscera and expressed as percentage

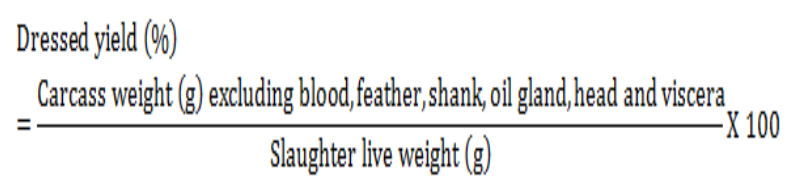

\section{Giblet yield}

The weight of heart, liver and gizzard were weighed and collectively recorded as giblet yield ( $\mathrm{g}$ ) and expressed as percentage of live weight as follows:

Giblet yield $(\%)=\frac{\text { Weight of heart, liver and gizzard }(\mathrm{g})}{\text { Slaughter live weight }(\mathrm{g})} \times 100$ 


\section{Cut up parts}

The weight of individual cut up parts were recorded and expressed as percentage of live weight as follows:

Cut up parts weight $(\%)=\frac{\text { Weight of individual cut }- \text { up part }}{\text { Dressed weight }} \mathrm{X} 100$

\section{Statistical analysis}

Data, thus collected, was subjected to statistical analysis by analysis of variance using Completely Randomized Design as described by Snedecor and Cochran (2002). The treatment means were compared by critical differences (CD).

\section{Results and Discussion}

The effect of supplementation of phytobiotics on carcass traits like processing yields are presented in Tables 2, processing loss and offal weights in table 3 and cut-up parts in Table 4.

\section{Per cent eviscerated weight and ready-to- cook weight}

The values of per cent eviscerated weight and ready-to-cook weight obtained in this study are presented in Table 2. The treatment groups T4 (63.66\%), T3 (62.57\%) and T2 $(61.65 \%)$ recorded significantly $(\mathrm{P}<0.05)$ higher eviscerated carcass yield compared to control $(58.42 \%)$.

Although the giblet weight alone did not differ among different treatment groups, the giblets with dressed weight was significantly $(\mathrm{P}<0.05)$ high in $\mathrm{T} 3 \quad(67.73)$ and $\mathrm{T} 4$ (69.71).Similar observations of significant $(\mathrm{P}<0.05)$ difference in the carcass traits including dressing percentage in broiler chicken due to inclusion of turmeric powder in the diet was made by Hussein(2013) and
Mondal et al., (2015). In contary, Nouzarian et al., (2011), Noori et al., (2011), Al-Jaleel (2012), Mashhadani (2015), Wang et al., (2016) and Hidayat et al., (2017) reported no significant effect on carcass quality traits including dressed weight and dressing percentage due to supplementation of turmeric powder. Similarly Kirubakaran et al., (2016) reported that incorporation of 5 and $10 \mathrm{~g}$ garlic powder/ $\mathrm{kg}$ diet, resulted in insignificant difference in dressed weight (73.89 and $73.97 \%$ respectively) than control $(73.78 \%)$.

The result of present study agrees with earlier findings of Milosevic et al., (2013). Rinkesh et al., (2015) showed that significantly $(\mathrm{P}<0.05)$ higher dressing percentage was observed in 0.1 per cent as compared to 0.5 per cent garlic supplementation and control; however, eviscerated yield remained comparable $(\mathrm{P}>0.05)$ among different dietary treatment groups.

Ashayerizadeh et al., (2009) also reported significant $(\mathrm{P}<0.05)$ increase in dressing percentage in garlic supplementation. In contrast to present findings, Aji et al., (2011) reported non-significant effect of garlic supplementation on dressing percentage in broilers. Barad et al., (2017) supplemented the feed with coriander seed $(2 \%)$, turmeric powder $(2 \%)$ and black pepper $(0.5 \%)$ and found no significant difference in dressing percentage.

Karangiya et al., (2016)fed broiler chicken with $1 \%$ garlic or $1 \%$ ginger or $1 \%$ garlic + $1 \%$ ginger. They observed that $1 \%$ garlic had significant $(\mathrm{P}<0.05)$ effect on dressing percentage. A broiler trail conducted with supplementation of $0.2 \%$ ginger or pepper or curry leaf powder has shown that the carcass characteristics viz. eviscerated weights and ready-to-cook percentage did not differ significantly among treatment groups at 6 
weeks of age (Moorthy et al., 2009). Similar to the present findings, Ei-Deck et al., (2003) also observed no significant effect on dressing percentage of broilers fed with $0.1 \%$ ginger powder up to 6 weeks of age. Safa and Eltazi (2014) reported that diets with $1.5 \%$ garlic+ $0.25 \%$ ginger had significantly $(\mathrm{P}<0.05 \%)$ highest hot and cold dressing percentage of the broilers at 6 weeks of age.

Similarly, Dieumou et al., (2012) reported that carcass dressing percentage of broiler chicks fed on diets supplemented with garlic essential oil were significantly $(\mathrm{P}<0.05)$ better than control. Zomrawi (2013) recorded higher dressing percentage in birds receiving $1 \%$ ginger root powder diet in comparison to control.

Belalet.al. (2018) reported that dressing percentage were significantly higher in $0.15 \%$ ginger supplemented birds compared to $0.15 \%$ garlic, $0.7 \%$ ginger $+0.15 \%$ garlic powder feed supplemented groups and $0.15 \%$ ginger $+0.15 \%$ garlic water infused groups. The dressing percentage was also significantly $(\mathrm{P}<0.05)$ higher when ginger and garlic were fed in powder form.

\section{Organ weight}

The weights liver, heart and giblet were recorded in the present study did not differ significantly $(\mathrm{P}>0.05)$ among the different groups (Table 3). Similar to the present findings Patel et al., (2017) observed nonsignificant effect of garlic and fenugreek supplementation on weights of liver, heart and spleen in broilers.

Barad et al., (2017) also reported that the supplementations of feed with turmeric powder did not have any significant difference in weight of different organs. Kirubakaran et al., (2016) reported that the garlic fed groups had no significant difference in gizzard percentage when compared control at six weeks of age in broilers. Shewita and Taha (2018) reported non-significant differences in relative liver, heart, spleen and proventriculus percentages among the groups receiving different levels of ginger powder. Rinkesh et al., (2015) reported nonsignificant effect of garlic supplementation on relative weights of heart, liver and giblet.

The mean per cent weights of relative organs of broiler chicken on dressed weight basis did not differ significantly $(\mathrm{P}>0.05)$ among different treatment levels of turmeric powder groups except the per cent weight of liver. (Choudhury et al., 2019). Javandel et al., (2008) and Onibi et al., (2009) stated that garlic supplementation had no significant effects on organ characteristics. The present findings were in agreement with the observations of Noori et al., (2011), Al-Jaleel (2012), Maaty et al., (2014), Mashhadani (2015), Hady et al., (2016) and Yesuf et al., (2017), who found that relative organ weights of chicken were not significantly $(\mathrm{P}>0.05)$ affected by dietary supplementation of turmeric powder. In contrast to the present findings, Choudhury et al., (2019), found significantly $(\mathrm{P}<0.05)$ higher liver weight in turmeric supplemented groups.

Abou-Elkhair et al., (2014) and Maaty et al., (2014) found significant $(\mathrm{P}<0.05)$ increase in the mean weights of liver due to feeding of turmeric powder in broiler chickens. Kirubakaran et al., (2016) reported significantly $(\mathrm{P}<0.01)$ higher liver weight percentage in $10 \mathrm{~g}$ garlic powder $/ \mathrm{kg}$ of diet supplementation. Karangiya et al., (2016) reported that supplementation of ginger and garlic led to significant $(\mathrm{P}<0.05)$ increase in the weight of different visceral organs. Safa and Eltazi (2014) fed different levels of garlic and ginger powder and found that gizzard yield was significantly $(\mathrm{P}<0.05)$ decreased due to supplementation. 


\section{Processing loss}

All the processing loss like weights of blood, feather and shank had no significant difference among treatments (Table 3). Rinkesh et al., (2015) reported nonsignificant effect on blood and feather loss among different of levels of garlic supplemented groups. The other relative organs like head, shank, intestine, kidneys and pancreas showed non-significant $(\mathrm{P}>0.05)$ difference in three different levels of turmeric powder groups (Choudhury et al., 2019). Raeesi et al., (2010) stated that supplementation of 1 and $3 \%$ garlic in the broiler diet had no significant effects on digestive organs. Tekeli et al., (2011) who concluded that dietary supplementation of ginger had significant effects on the weight of visceral organs of broiler chickens.

\section{Small intestine length}

The small intestine length $(\mathrm{cm})$ showed significant $(\mathrm{P}<0.01)$ difference among the treatment groups. The turmeric $(179.83 \mathrm{~cm})$ and garlic $(175.33 \mathrm{~cm})$ supplemented birds had significantly $(\mathrm{P}<0.01)$ higher intestinal length than other groups. In contrast, Patel et al., (2017) also reported that the length of intestine and caecum had non-significant $(\mathrm{P}>0.05)$ difference due to the supplementation of garlic and fenugreek alone and in combination. Javandel et al., (2008) reported non-significant effect of garlic on intestine length of broilers.

\section{Cut-up-parts of carcass}

The cut-up-parts of different treatment groups were presented in Table 4 . The per cent yields of cut-up-parts like breast and back were significantly $(\mathrm{P}<0.05)$ higher in $\mathrm{T} 4$ $(27.30 \%)$ followed by T3 (27.10\%), T2 $(26.16 \%)$ and $\mathrm{T} 1(23.86 \%)$ respectively. The per cent thigh and wings were significantly
$(\mathrm{P}<0.05)$ higher in $\mathrm{T} 4$ followed by T3, T2 and T1. The per cent drumstick and neck did not differ significantly $(\mathrm{P}>0.05)$ among different treatment groups. Similar findings of significant $(\mathrm{P}<0.05)$ differences in per cent yield of breast were reported by Wang et al., (2016) in broiler chicken due to supplementation of turmeric powder in the basal diet. Hussein (2013) and Ukoha and Ununkwo (2016) found significant $(\mathrm{P}<0.05)$ differences in per cent yields of thigh and back between the control and turmeric supplemented groups.

In, contrary to the present findings, Durrani et al., (2006) and Mashhadani (2015) found non-significant differences in the per cent yield of breast, thigh, back and wings among the control and turmeric powder fed groups. Similarly, Choudhury et al., (2019) reported per cent yields of cut-up-parts like neck and drumsticks did not differ significantly $(\mathrm{P}>0.05)$ among different treatment groups. Similar to the present findings, Durrani et al., (2006) and Mashhadani (2015) found nonsignificant difference in per cent yields of drumsticks and neck in turmeric powder feed group. Raeesi et al., (2010) reported significant effect on carcass parts of broilers fed with garlic. Oleforuh-Okoleh et al., (2014) reported that $0.1 \%$ ginger powder, $0.1 \%$ garlic powder in feed, $50 \mathrm{ml} /$ litre ginger or garlic infusion through water significantly $(\mathrm{P}<0.05)$ influenced carcass parts of 7 week old broilers. In contrary to the present results, Dieumou et al., (2009) and Pourali et al., (2010) reported that the carcass parts were not affected by ginger and garlic. Zomrawi (2013) reported that the percentages of commercial cuts like breast showed significant $(\mathrm{P}<0.05)$ improvement at different levels of garlic and ginger powder in broiler diets. Safa and Eltazi (2014) reported that the diets with $11.5 \%$ garlic $+0.25 \%$ ginger significantly $(\mathrm{P}<0.05)$ increased the commercial cuts percentage like breast and thigh. 
Table.1 Experimental design

\begin{tabular}{|c|l|c|c|}
\hline Group & Treatment & Replicates & $\begin{array}{c}\text { Total no. of } \\
\text { birds }\end{array}$ \\
\hline T1 & Basal diet (control) & 3 & 30 \\
\hline T2 & Basal diet + Ginger powder $0.50 \%$ & 3 & 30 \\
\hline T3 & Basal diet + Garlic paste $0.50 \%$ & 3 & 30 \\
\hline T4 & Basal diet +Turmeric powder0.50\% & 3 & 30 \\
\hline
\end{tabular}

Table.2 Effect of phytobiotics on processing yield of Nandanam broiler -3 (Mean \pm S.E)

\begin{tabular}{|c|c|c|c|c|c|}
\hline Parameters & T1 (Control) & $\begin{array}{l}\text { T2 ( } 0.50 \% \\
\text { Ginger } \\
\text { powder) }\end{array}$ & $\begin{array}{l}\text { T3 }(0.50 \% \\
\text { Garlic paste) }\end{array}$ & $\begin{array}{l}\text { T4 }(0.50 \% \\
\text { Turmeric } \\
\text { powder) }\end{array}$ & F-value \\
\hline Live wt. (g/bird) & $1129.33 \pm 24.71$ & $1114.17 \pm 30.20$ & $1174.17 \pm 25.70$ & $1133.17 \pm 31.34$ & $0.8314^{\mathrm{NS}}$ \\
\hline Eviscerated wt (\%) & $58.42 \pm 1.04^{b}$ & $61.65 \pm 1.26^{\mathrm{a}}$ & $62.57 \pm 0.90^{\mathrm{a}}$ & $63.66 \pm 0.64^{\mathrm{a}}$ & $5.251 * *$ \\
\hline Giblet wt (\%) & $5.10 \pm 0.481$ & $5.67 \pm 0.39$ & $5.16 \pm 0.15$ & $6.05 \pm 0.31$ & $1.615^{\mathrm{NS}}$ \\
\hline $\begin{array}{l}\text { Ready-to-cook wt } \\
(\%)\end{array}$ & $63.52 \pm 1.24^{\mathrm{b}}$ & $67.31 \pm 0.97^{b}$ & $67.73 \pm 0.87^{\mathrm{a}}$ & $69.71 \pm 0.88^{\mathrm{a}}$ & $6.672 * *$ \\
\hline \multicolumn{6}{|l|}{ Weight of Giblet } \\
\hline Liver (\%) & $2.52 \pm 0.26$ & $2.57 \pm 0.20$ & $2.44 \pm 0.10$ & $3.09 \pm 0.36$ & $1.427^{\mathrm{NS}}$ \\
\hline Heart (\%) & $0.53 \pm 0.07$ & $0.37 \pm 0.06$ & $0.53 \pm 0.01$ & $0.55 \pm 0.08$ & $1.988^{\mathrm{NS}}$ \\
\hline Gizzard (\%) & $2.04 \pm 0.24^{b}$ & $2.73 \pm 0.21^{\mathrm{a}}$ & $2.18 \pm 0.06^{\mathrm{b}}$ & $2.40 \pm 0.05^{\mathrm{a}}$ & $3.2621^{*}$ \\
\hline
\end{tabular}

** Significant $(\mathrm{P}<0.01)$; *- Significant $(\mathrm{P}<0.05)$; NS-Not Significant $(\mathrm{P}>0.05)$

Mean values within each row bearing common superscripts do not differ significantly (P0.05)

Table.3 Effect of phytobiotics on processing loss and weight of the offal of Nandanam broiler -3 (Mean \pm S.E)

\begin{tabular}{|c|c|c|c|c|c|}
\hline Parameters & T1 (Control) & $\begin{array}{l}\text { T2 }(0.50 \% \\
\text { Ginger } \\
\text { powder })\end{array}$ & $\begin{array}{l}\text { T3 ( } 0.50 \% \\
\text { Garlic paste) }\end{array}$ & $\begin{array}{l}\text { T4 }(0.50 \% \\
\text { Turmeric } \\
\text { powder })\end{array}$ & F- value \\
\hline Blood wt. (\%) & $5.63 \pm 0.73$ & $4.37 \pm 0.34$ & $4.04 \pm 0.27$ & $4.02 \pm 0.57$ & $2.2023^{\mathrm{NS}}$ \\
\hline $\begin{array}{l}\text { Feather loss with } \\
\text { skin }(\%)\end{array}$ & $13.04 \pm 1.04$ & $11.60 \pm 0.36$ & $11.64 \pm 0.41$ & $11.01 \pm 0.16$ & $2.133^{\mathrm{Ns}}$ \\
\hline Head wt. (\%) & $3.28 \pm 0.19^{b}$ & $3.96 \pm 0.07^{\mathrm{a}}$ & $3.16 \pm 0.08^{b}$ & $3.74 \pm 0.19^{\mathrm{a}}$ & $6.767 * *$ \\
\hline Shank wt. (\%) & $4.13 \pm 0.46$ & $5.18 \pm 0.25$ & $4.40 \pm 0.21$ & $4.93 \pm 0.24$ & $2.3616^{\mathrm{NS}}$ \\
\hline Liver wt. (\%) & $2.52 \pm 0.26$ & $2.57 \pm 0.20$ & $2.44 \pm 0.10$ & $3.09 \pm 0.36$ & $1.427^{\mathrm{NS}}$ \\
\hline Heart wt. (\%) & $0.53 \pm 0.07$ & $0.37 \pm 0.06$ & $0.53 \pm 0.01$ & $0.55 \pm 0.08$ & $1.988^{\mathrm{NS}}$ \\
\hline Gizzard wt. (\%) & $2.04 \pm 0.24^{b}$ & $2.73 \pm 0.21^{\mathrm{a}}$ & $2.18 \pm 0.06^{\mathrm{b}}$ & $2.40 \pm 0.05^{\mathrm{a}}$ & $3.2621 *$ \\
\hline Intestine wt (\%) & $7.56 \pm 0.22$ & $7.26 \pm 0.58$ & $7.24 \pm 0.27$ & $8.87 \pm 0.14$ & $1.386^{* *}$ \\
\hline Intestine length(cm) & $141.50 \pm 4.36^{\mathrm{b}}$ & $139.50 \pm 8.26^{b}$ & $175.33 \pm 7.91^{\mathrm{a}}$ & $179.83 \pm 5.44^{\mathrm{a}}$ & $10.313 * *$ \\
\hline
\end{tabular}


Table.4 Effect of Phytobiotics on cut-up-parts of Nandanam broiler -3 (Mean \pm S.E)

\begin{tabular}{|l|l|l|l|l|c|}
\hline Parameters & $\begin{array}{l}\text { T1 } \\
\text { (Control) }\end{array}$ & $\begin{array}{l}\text { T2 } \mathbf{( 0 . 5 0 \%} \\
\text { Ginger } \\
\text { powder) }\end{array}$ & $\begin{array}{l}\text { T3 }(\mathbf{0 . 5 0 \%} \\
\text { Garlic } \\
\text { paste) }\end{array}$ & $\begin{array}{l}\text { T4 (0.50\% } \\
\text { Turmeric } \\
\text { powder) }\end{array}$ & F- value \\
\hline Breast (\%) & $23.86 \pm 0.48^{\mathrm{b}}$ & $26.16 \pm 0.55^{\mathrm{a}}$ & $27.10 \pm 0.77^{\mathrm{a}}$ & $27.30 \pm 1.27^{\mathrm{a}}$ & $3.636^{*}$ \\
\hline Back (\%) & $14.68 \pm 0.18^{\mathrm{b}}$ & $15.20 \pm 0.71^{\mathrm{b}}$ & $16.87 \pm 0.49^{\mathrm{a}}$ & $16.17 \pm 0.32^{\mathrm{a}}$ & $4.316^{*}$ \\
\hline Thigh (\%) & $14.48 \pm 0.42^{\mathrm{b}}$ & $15.18 \pm 0.39^{\mathrm{b}}$ & $16.89 \pm 0.33^{\mathrm{a}}$ & $17.53 \pm 0.45^{\mathrm{a}}$ & $12.737^{* *}$ \\
\hline Drumstick(\%) & $14.77 \pm 0.41$ & $16.19 \pm 0.39$ & $15.89 \pm 0.41$ & $15.75 \pm 0.68$ & $1.580^{\text {NS }}$ \\
\hline Neck(\%) & $9.41 \pm 0.66$ & $9.43 \pm 0.29$ & $8.70 \pm 0.44$ & $7.61 \pm 0.48$ & $3.077^{\text {NS }}$ \\
\hline Wings (\%) & $13.27 \pm 0.57^{\mathrm{b}}$ & $15.39 \pm 0.13^{\mathrm{a}}$ & $14.56 \pm 0.20^{\mathrm{a}}$ & $14.78 \pm 0.27^{\mathrm{a}}$ & $7.009^{* *}$ \\
\hline
\end{tabular}

It could be concluded that $0.50 \%$ turmeric powder supplementation can benefit broilers in terms of per cent eviscerated, giblet and ready-to-cook weight and carcass cut-upparts like per cent breast, back and weight. Therefore, turmeric powder at 0.50 per cent level in feed can be recommended as nonantibiotic feed supplement for better carcass traits in colour broilers like Nandanam broiler-3.

\section{Acknowledgement}

Authors are thankful to the Director, Centre for Animal Production Studies, Tamil Nadu Veterinary and Animal Sciences University, Madhavaram Milk Colony, Chennai, Tamil $\mathrm{Nadu}$, India for the necessary facility provided during this experiment.

\section{References}

Abou-Elkhair, R., Ahmed,HA., Selim,S, 2014. Effects of Black Pepper (Pepper Nigrum), Turmeric Powder (Curcuma longa) and Coriander Seeds (Coriandrum sativum) and their combinations as Feed Additives on Growth Performance, Carcass Traits, Some Blood Parameters and Humoral Immune Response of Broiler Chickens. Asian Australias. J.Anim.Sci., 27(6): 847-854.

Aji, S.B., Ignatius, K., Ado, Y.A., Nuhu, J.B.,
Abdulkarim, A., Aliyu, U., Gambo, M.B., Ibrahim, M.A., Abubakar, H., Bukar, M., Imam, H.M. and Numan, P.T. 2011. Effect of feeding onion and garlic on some performance characteristics of broiler chicken. Res.J.Poul. Sci.,. 4(2): 22-27.

Al-Jaleel RAA. Use of turmeric (Curcuma longa) on the performance and some physiological traits on the broiler diets, 2012. The Iraqi J. Vet.Med., 36(1):5157.

Ashayerizadeh, A., Dastar, B., Rahmatnejad, E., Shargh, M.S., Ashayerizadeh, O. and Hossaini, S.M.R. 2009. Use of garlic (Allium sativum), black cumin seeds (Nigella sativa L.) and wild mint (Menthalongifolia) in broiler chicken diets.J.Anim. Vet. Adv., 8: 1860-63.

Barad,N.A., $\quad$ Savsani,H.H., $\quad$ Patil,S.S., Gadariya, M.R., Murthy,K.S and Fefar, D.T. 2017. Effect of supplementing the diet with Coriander Seeds, Turmeric Powder and Black Pepper on the Feed Intake, Growth Performance and Carcass quality of Broilers. Indian Vet.J.,94(11): 43-45.

Belal, SA.,Uddin,MN., Hasan,MK., Islam,MS and Islam, MA. 2018. Effect of ginger (Zingiber officinale) and garlic (Allium sativum) on productive performance and haematological parameters of broilers.Int.J.Agri.\& Eniv.Res.,4(1): 1223. 
BIS. 2007. Indian Standard: Poultry Feed Specifications. 5th Revision.Bureau of Indian Standards, New Delhi.

Botsoglou,NA., $\quad$ Florou-Paneri,P., Christaki,E., Fletouris,DJ and Spairs, AB.2002. Effect of dietary oregano essential oil on performance of chickens and on iron- induced lipid oxidation of breast,thigh and abdominal fat tissues. British.Poult.Sci., 43 :223-230.

Choudhury, D., Mahanta,JD ., Sapcota,D. and Saikia, BN.2019. Effect of dietary supplementation of turmeric (Curcuma longa) powder on the carcass quality of commercial broiler chicken.Int.J.Food Sci. \&Nutr., 4 (1) : 27-31.

Dieumou,F.E., Tegula,A., Kuiate,J.R., Tamokou,J.D, Fong, N.B and Dongmo, M.C.2009. Effects of ginger (Zingiberofficinale) and garlic (Allium sativum) essential oils on growth performance and gut microbial population of broiler chickens. Livestock Research for Rural Development.Vol.21.

Durrani,FR., Ismail,M., Sultan,A., Suhail, SM., Chand,N and Durrani, Z. 2006. Effect of different levels of feed added turmeric (Curcuma longa) on the performance of broiler chicks. J.Agri.Biol.Sci., 1 (2) : 9-11.

El-Deck,A.A., Attia,Y.A and Hannfy, M.M. 2003.Effect of anise (Pimpinella anisum), ginger (Zingiber officinale roscoe) and fennel (Foeniculum vulgare) and their mixture on performance of broilers. Archiv fur Geflugelkunde. 67 : 92-96.

Hady,MM.,Zaki,MM., WafaaAbd EL-Ghany, WA., and RedaKorany, MS.2016. Assesssment of the broiler performance, gut healthiness and carcass characteristics in response to dietary inclusion of dried coriander, turmeric and thyme.Int.J. Environmental and Agri.Res., 2 (6): 153-159.
Hidayat, M., ZuprizalSundari, Kurniawati,A., Wati, AK and Kusmayadi, A.2017.The effect of liquid turmeric extract supplementation on carcass production and chemical quality of broiler meat.J.Indonesian Tropical Anim.Agri., 42 (1):6-13.

Hussein, SN.2013. The Tuemeric (Curcuma longa) powder on growth performance, carcass traits, meat quality and serum biochemical parameters in broilers.J.Adv.Biomed.Pathol.Res. 3 (2) :25-32.

Iji,P.A., Saki, A., and Tivey, D.R.2001. Body and international growth of broiler chicks on a commercial starter diet, Intestinal weight and mucosal development. British Poultry Sci.,42 : 505-513.

Javandel,F., Navidshad, B., Seifdavati, J., Pourrahimi,G.H and Baniyaghoub, S.2008. The favourite dosage of garlic meal as a feed additive in broiler chickens ratios.Pakistan J.Biolog.Sci.,11(13): 1746-1749.

Karangiya, V.K., Savsani, H.H., Shrikant Soma Patil, Garg, D.D., Murtht, K.S, Ribadiya, N.K and Vekariya, S.J. 2016. Effect of dietary supplementation of garlic, ginger and their combination of feed intake, growth performance and economics in commercial broilers.Vet.World.9: 245-250.

Kirubakaran, A., Moorthy, M., Chitra, R and Prabakar, G. 2016. Effect of Phytoadditive Supplementation on Broiler Carcass Characteristics, 2016. Indian Vet.J., 93 (12): 18-20.

Maaty,A., Hayam,MA., Rabie,MH., and ElKhateeb, AY.2014.Response of heatstressed broiler chicks to dietary supplementation with some commercial herbs.Asian J. Anim. and Vet. Advances. 9 (12): 743-755.

\begin{tabular}{|c|c|}
\hline MK., & Kazemi, \\
\hline
\end{tabular}


germander (Trucrium polium) and watercress (Nasturtium officinale) extract on performance, carcass quality and blood metabolites of males broilers.Res.Opinion

Anim.\&Vet.Sci., 2: 66-68.

Mashhadani,HE. 2015. Effect of different levels of turmeric (Curcuma longa) supplementation on broiler performance, carcass characteristic and bacterial count. Egyptian Poult.Sci.J., 35 (1) : 25-39.

Milosevic,N., Stojcic,M.D., Stanacev,V., Peric,L and Veljic, M.2013.The performance and carcass traits of broilers feed with garlic(Allium sativum)

additive.http://www.wpsa.com/proceedi ngs/ESPN-2013/assets/pdf/0053.pdf.

Mondal MA, Yeasmin T Karim R, Siddiqui MN, Raihanun-Nabi SM, Sayed MA and Siddiky, MNA. 2015. Effect of dietary supplementation of turmeric (Curcuma longa) powder on the growth performance and carcass traits of broiler chicks. SAARC Journal of Agriculture. 13(1):188-199.

Moorthy M, Ravi KM and Edwin, SC. 2009. Ginger, pepper and curry leaf powder as feed additive in broiler diet. Inter. J. Poult. Sci., 8(8):779-782.

Noori,MA., Hossain,AB., Al-Maahidy, AHA., Rawi,S and JAI,. 2011. The effect of dietary Curcuma longa powder (Turmeric) supplementation on some blood parameters and carcass traits of broiler chickens. AI-Anbar J.Vet.Sci., 4 :69-74

Nouzarian.,R, Tabeidian., SA, Toghyani., M, Ghalamkari., and Toghyani, M 2011.Effect of turmeric poeder on performance, carcass traits, humoral immune responses, and serum metabolites in broiler chickens. J.Anim. and Feed Sci., 20:389-400.

Oleforuh-Okoleh, V.U., Chukwu, G.C. and
Adeolu, A.I. 2014.Effect of ground ginger and garlic on the growth performance, carcass quality and economics of production of broiler chickens.Glob.J.Biosci.Biotechnol., 3 (3) : 225-229.

Onibi, G.E., Oluwatoyin, E., Adebisi, A., Fajemisin, N., Ayode, V and Adetun, J.I. 2009.Response of broiler chickens in terms of performance and meat quality to garlic (Allium satuvum) supplementation.African . J. Agr. Res., 4 (5): 511-517.

Patel, R.M., Garg, D.D., Vahora, S.G., Raval, A.P and Choubey M. 2017. Effect of dietary supplementation of garlic (Allium sativum) and Fenugreek (Trionellafoenum-graecum L.) seed powder on growth performance, carcass characteristics and economics of feeding in broilers. J. Anim. Res., 7 (2): 313-318.

Pourali, M., Mirghelenji, S.A., and Kermanshahi, H.2010. Effects of garlic powder on productive performance and immune response of broiler chickens challenged with Newcastle disease virus. Global Veterinarian. 4 (6): 61621.

Raeesi, M., Hoseini-Aliabad, A., Roofchaee, A., Zareshahneh, A. and Pirali, S. 2010. Effect of periodically use of garlic (Allium sativum) powder on performance and carcass characteristics of broiler chickens. World Academy. Sci. Engin. Tech., 44.

Rinkesh,BM., $\quad$ Ajay,PR.,Haresh,DC., Ram,CK., Amit,KS., Shekhar,RB and Bharat, BR. 2015.Effect of Garlic(Allium sativum) supplementation on growth performance, carcass characteristics and economics of broilers. J.Anim.Res., 5 (4) : 843-848

Safa,M.A. Eltazi,2014.Response of broiler chicks to diets containing different mixture levels of garlic and ginger 
powder as Natural feed additives, Int.J.Pharm.Res.\&All.Sci., 3 (4): 27-35

Shewita,R.S and Taha, A.E.2018. Influence of dietary supplementation of ginger powder at different levels on growth performance, haematological profiles, slaughter traits and gut morphometry of broiler chickens, South African.J.Anim.Sci., 48(6): 997-1008.

Snedecor, G. W. and Cochran, W. G. (2002) Statistical Methods, 8th Edition, Oxford and IBH publishing company Calcutta, Bombay and New Delhi.

Tarhyel,R., Hena,SA., and Tanimomo, BK.2012.Effect of age on organ weight and carcass characheteristics of Japanese quail (Coutrnixcoutrnix japonica).Scientific Journals-Agis. 1(1):21-26

Tekeli,A., Kutlu,HR., and Celik, L.2011.Effect of Z.officinale and propolis extracts on the performance, carcass and some blood parameters of broiler chicks. Current Res.in Poult.Sci., 1(1): 12-23.

Ukoha,OA and Ununkwo, DN.2016.The effect of Turmeric (Curcuma longa) on growth performance of broiler chickens.Int.Res.J.Agri.Aqua.Sci., 3(4):131-135

Wang,D., Huang,H., Zhou,L., Wei Li, Zhou,H ., Hou,G ., Liu., J and Hu, 1. 2016. Effects of dietary supplementation with Turmeric Rhizome extract on growth performance, carcass characteristics, Antioxidant capability and meat quality of Wenchang broiler chickens.Italian J.Anim.Sci., 14: 344-349.

Yesuf, KY., Mersso,BT., Bekele,TE.2017. Effects of different levels of turmeric, fenugreek and black cumin on carcass characteristics of broiler chicken.J.Livestock Sci., 8:11-17.

Zomrawi,W.B., Abdel, Atti, K.A.A., Dousa,B.M. and Mahala, A.G. 2013.The effect of dietary ginger root powder(Zingiberofficinale) on broiler chicks, performance,carcass characteristics and serum constitutents , J.Ani.Sci.Advance.3:42-47.

\section{How to cite this article:}

Sangilimadan. K., R. Richard Churchil, K. Premavalli, S. T. Selvan and Omprakash. A. V. 2020. Effect of Phytobiotics Supplementation on Carcass Characteristics of Nandanam Broiler 3 Chicken. Int.J.Curr.Microbiol.App.Sci. 9(05): 1349-1358.

doi: https://doi.org/10.20546/ijcmas.2020.905.152 